\title{
VENEREAL DISEASES IN THE SOVIET UNION
}

becoming such a rarity that medical schools experience considerable difficulty in finding cases for demonstration purposes.

One final independent testimony, although at third hand, is worth noting. Dyson Carter, in Russia's Secret Weapon, quotes Quentin Reynolds's report that Commander Norman, a member of the Harriman Mission and health officer with the American Embassy, made this statement: "The Red Army and the Air Force are virtually free from venereal disease. You can't say that about any other army in the world. As a doctor that impresses me.',

\section{DISCUSSION}

Brig. T. E. Osmond (the President) said that he had had no idea that Russia had achieved such extraordinary results in her venereal diseases campaign, although he had received some information when he met a Colonel in the Red Army who assured him that venereal disease was not a problem in the Russian Army.

Were all the medical officers salaried and if so what sort of pay did they receive ? How high did they stand in the social scale from the financial point of view? The Russian idea of postgraduate teaching should certainly be a lesson for this country. He liked the idea of mobile units. It had been proposed that mobile units should be formed in Great Britain but the suggestion had been turned down. He had also proposed them for the Army, but they were found not to be practicable. He hoped they would come and would solve the problem of the rural areas.

Dr. Scott replied that he went into the question of pay very carefully but there was absolutely not a basis of comparison. All the essentials of life were provided by the State at a low cost and it was only on luxuries that money was spent. There was therefore no basis of comparison between what the Russian worker in any sphere received and what the worker in a capitalist country received. The highest paid workers in Russia quite properly were those in leper institutions, who received in actual cash something like 900 roubles a month, which was about $£ 45$ per month in English money. The whole basis of values was essentially different ; private enterprise was completely abolished, there was no such thing as interest, savings could be accumulated but interest was not paid. He gathered that the Russians did not claim that they were as yet a communist state, but that they were definitely and decidedly a socialist state and that they were on the way to communism.

Some of the analogies with the "White Paper", were particularly striking, and the parallels between the Russian system and the proposals put forward by Sir William Beveridge for social security organization were even more striking. It was interesting that it had been able to stand the shock of Hitler getting the best part of Russia and the Russians being able to hit back at him as they had done. However totalitarian the institutions were, he gathered that the U.S.S.R. was a very rare and genuine democracy. When the Moscow Soviet was being elected no less than 100,000 resolutions were passed by the people who were doing the electing. They could talk as much as they liked and it influenced the Government. People were encouraged to talk, but once marching orders were issued they had to be obeyed.

\section{Dr. Shanson asked whether or not the arsenicals and sulphonamides were used.}

Dr. Scatt replied that as far as he knew they were used. The Russians were making their own arsenicals and sulphonamides just as we were. They had a preparation about which we did not seem to know very much, a combination of glucose with sulphonamide which they called glucostreptocide, with almost twice the weight of sulphonamide. Glucose had an almost similar molecular weight to sulphonamide. They were using the preparation in the treatment of the soft chancres; otherwise they were working on much the same lines as in Great Britain in syphilis and in gonorrhoea. They were claiming that they could do the Wassermann test with the use of human serum for the complement test.

Lt.-col. D. J. Campbell said that in order to produce such a large decrease in the incidence of venereal disease in a country which had been looked upon as almost illiterate, there must have been a tremendous propaganda campaign. Could Dr. Scott say anything about the way in which it was carried out, because this was one of the greatest problems?

Dr. Scott replied that one could almost say that communism meant propaganda. Inside the factories, the largest of which employed from 40,000 to 50,000 workers, they had wall newspapers, clubs, posters and cinemas. Once the People's Commissar of Public Health made up his mind that a certain line was to be followed the word passed down the whole chain and to the various officials connected with the administration departments. One of the things they were short of was permanent officials, and a tremendous amount of work was still done voluntarily by the people elected to the Soviets and by ordinary citizens. It was a regular custom in Moscow for thousands to give up their free afternoon to go and do the work done in this country by paid officials. The Communist Party gave the lead and, if there was a problem, in every single administration unit in every single Communist cell it was dealt with. In the factories there were medical departments which in many cases were better than our hospitals, and any health work necessary could be undertaken. 
THE BRITISH JOURNAL OF VENEREAL DISEASES

Dr. R. Forgan said that this immense work on health education in the factories in Russia was a challenge when it was compared with what was being done in England at the present time. It was perfectly true that the Ministry of Health and Ministry of Labour were encouraging health education in factories, but they were very far from the Russian plan. He might contrast the attitude of the Government towards V.D. matters in Russian factories and in British factories. A couple of years ago, when it was suggested that there should be a brief reference to the necessity for any individual who thought he or she might be infected with venereal disease to consult a doctor or attend a clinic, in a leaflet which was being circulated in factories, the Ministry of Labour objected. The Ministry of Health was able to persuade the Ministry of Labour that it was backward, but he hoped that Dr. Scott and other doctors would do their utmost to spread health education in this country.

\section{Dr. Shanson asked whether the bottle of medicine mania existed in Russia as it did here.}

\section{Dr. Scott said that he did not know.}

Dr. Nabarro asked whether there were any figures available for the incidence of congenital syphilis in the U.S.S.R. or whether they had any records from 1914 onwards. One would like to have some idea of the amount of antenatal work which had been done since just before the war and in the early days after the revolution. It would be interesting to know whether or not the tremendous improvement in the venereal condition in the U.S.S.R. was reflected in the number of cases of congenital syphilis which were reported. Another point was what relation the improved venereal position had to general paralysis of the insane and to tabes-whether the figures had improved in the last twenty-five years.

He was scared by what Dr. Scott had said. It was almost inconceivable that in such a vast area these improvements could have been effected in twenty-five years, especially in the rural districts. How could these diseases be attacked and the patients diagnosed ? He supposed that it was the mobile clinics which had accomplished it. It seemed to the speaker that if this state of affairs could be brought about in such an enormous country, then it should be child's play in a country like Great Britain, if there were the will to do it ; but it seemed that the will was not there.

Dr. Scott said that he had no figures on tabes and G.P.I., but he realized that they would be of enormous value as a check on the other figures. He had a note which Professor Sarkisov had kindly supplied, but all he said about congenital syphilis was that special attention had been paid to that side and that a new and rapid method of treatment and prevention had been found ; no details were given.

Dr. Curtis said that Dr. Scott had mentioned a " reasonable attitude to venereal disease". Could he amplify that expression a little, particularly in relation to the mobile units ? One of the alleged disadvantages accompanying the use of mobile units in this country was that if venereal treatment were "driven up in a plain van", everyone would guess what it was all about. He wondered whether, if mobile units were so much used in Russia, that particular attitude had boen overcome and if so whether it was as a result of the propaganda from the dispensaries in the villages.

Dr. Scott replied that that was an interesting point. He had taken the words in his paper very carefully from Professor Sigerist's book, Socialised Medicine in the Soviet Union, which were "a rational attitude". The Russians dealt with venereal diseases on sound medical lines without bringing in any particular racial or religious taboos. The encouragement of early marriage and the facilities for divorce (which incidentally had been tightened up considerably) tended to discourage promiscuity, and this had been one of their objects.

Lt.-col. J. M. Elliott said that he had been told that the people in Russia were living in appalling housing conditions, five and six families to a room. How did Dr. Scott reconcile that with his statements?

Dr. Scott said that the big cities were very overcrowded; the figures proved that. They were improving the situation but the war had intensified the problem. During the retreat the Russians had destroyed everything themselves, then the Germans destroyed everything. What kind of a problem had to be faced he did not know ; it was horrible to think about. Even in London there was a very real housing problem ; first-aid repairs were done very quickly but the whole problem was becoming very serious.

\section{Gonococcus and meningococcus : interchange of habitat}

Jean Armytage, of the Fairfax Institute of Pathology in Sydney, reported to the Society of Experimental Biology of New South Wales on one case of gonococcal meningitis, one of meningococcal vulvovaginitis and 3 cases of meningococcal conjunctivitis. In the case of the patient with meningitis, a culture from the cerebrospinal fluid produced small translucent colonies of Gram negative diplococci and it was not realized that these were not meningococci until, after recovery under sulphonamide treatment from the meningitis, the patient remained pyrexial and an epididymitis without free discharge developed. Prostatic massage produced material a culture from which was compared with the previous meningeal strain and fermentation reactions from both, with their "ability to be emulsified", showed them to be gonococci. -The Medical Journal of Australia, 30th September 1944. 